\title{
Maternity Legislation in Sri Lanka: Are Women Equal, Special or Different?
}

\author{
Sunethra M E Goonetilleke* \\ Department of Legal Studies, The Open University of Sri Lanka
}

\begin{abstract}
Pregnancy, childbirth and breast feeding are uniquely female experiences. While a woman's role in reproduction fulfills the important social function of ensuring the continuity of the human race, it is also one which challenges her endeavour to enter the public sphere of paid employment. The creation and maintenance of a public and private divide and the setting of norms in the public sphere on the basis of male standards are barriers women have long fought to surmount.
\end{abstract}

The aim of this paper is to study the laws governing maternity benefits in Sri Lanka, in order to uncover the foundations on which these laws are built. The study is normative in nature, focusing on applicable legislation in Sri Lanka. Therefore it discusses the provisions containing maternity benefits in the shop and Office Employees Act, the Maternity Benefits Ordinance and the provisions of the Establishment Codes relevant to state sector employees including university employees. The benefits studied are maternity leave, pay, nursing intervals, job security, health and safety of mother and child, paternity benefits and crèche facilities. The paper then critically analyzes and compares the applicable laws. It concludes by highlighting the lack of uniformity among the legislation and investigating the likely rationales for this difference through a feminist lens focusing on the public-private divide, and the 'equality' and 'different' or 'special' approaches.

Keywords - Maternity benefits, feminism, maternity benefits

*Correspondence should be addressed to Ms. Sunethra M. E. Goonetilleke. Department of Legal Studies, The Open University Sri Lanka, Nawala, Sri Lanka. (Email: mailforsunethra@gmail.com) 
ordinance, shop and office employees act

\section{Introduction}

\section{Background of the study}

Since time immemorial, women have been recognized as the primary care givers of children. Women, who in early times did not go to work outside the home, maintained the house, did the daily housework and raised the children.

The modern woman holds a full time job outside her home, and continues to fulfill her traditional role of caring for and raising the family. According to data regarding the first quarter of 2014 collected by the Department of Census and Statistics, 35.5\% of the economically active population (i.e. the labour force) of 8.8 million Sri Lankans, were women; $31.6 \%$ of the urban sector, $35.9 \%$ of the rural sector and $44.1 \%$ of the estate sector employees were female. In the first quarter of 2015 the economically active population increased to 8.9 million and the percentage of women to $36.7 \%$; $35.1 \%$ in the urban sector, $36.5 \%$ in the rural sector and $46.5 \%$ in the estate sector respectively. This data indicates that the female labour force though less than the male, is growing steadily. It also shows that women are actively involved in all the major sectors of employment, though the largest number is employed in the estate sector.

The Labour Survey Annual Report 2014 records female labour force participation as $34.7 \%$. 37.7\% of women aged between $20-24$ years, $41.5 \%$ belonging to the age group $25-29$ years and $43.6 \%$ of the age group from 30-34 years were employed in 2014. This indicates that a large portion of the working women were within the child-bearing age.

In the light of the above data it could be assumed that many women will enter motherhood while in employment. It is therefore mandatory that there be sufficient legislation to protect a woman's job during her maternity and to provide her with maternity benefits, primarily maternity leave to help her to cope with her dual role as care giver and employee.

\section{Nature and scope of the study}

On a global scale, the entry of woman into the workforce took place without any allowance being made for her then primary social role of child bearer. She was not provided with any special leave entitlement or guarantee of a job on returning after childbirth. Nor 
was any monetary support provided during her absence from work to deliver the baby. Thus she entered a space which had until that point of time been a male domain tailored for men with no alterations being made to suit her own femininity.

It is a positive feature that the Sri Lankan legal system has, in this field, as in most others governing the labour force, adopted a proemployee stance, by providing protected maternity leave to new mothers. Nevertheless, one of the drawbacks of the Sri Lankan law is that there is not one but several laws governing maternity, and that these laws lack uniformity. Thus, a women's leave entitlement differs merely by virtue of the sector to which her employment belongs and women placed in the same position due to pregnancy may be provided different treatment.

This is a situation which the author believes warrants a more critical examination. The objectives of this research are therefore:

- To review the existing laws governing maternity benefits, i.e. The Shop and Office Employment (Regulation of Employment and Remuneration) Act, The Wages Board Ordinance, The Establishment Code and relevant Circulars in Sri Lanka;

- To compare the content of these statutes and uncover the differences between treatment afforded to women in different sectors of employment; and

- To make suggestions for ensuring uniformity among women workers in Sri Lanka.

The author understands that developments in other countries have led to the very concept of leave for child care being broadened to include paternity and parental leave. However, this aspect is beyond the scope of this article which focuses more on studying the laws directly linked to leave granted to women at the time of entry of a new child into the family.

The primary benefit an employed mother-to-be would require is maternity leave to have the child, care for it immediately after birth and time to recover from childbirth. Apart from this, the assurance of her job being held for her pending her return to work and financial support until resumption of work, are also important maternity benefits. Some organizations do go beyond this to provide insurance or medical expenses as well. However, this paper focuses primarily on leave, pay and job security and the welfare of the mother and child. 


\section{Theoretical framework}

There are many feminist theoretical perspectives from which maternity legislation can be interpreted. The key distinction between the theories stems from the importance placed on the essential nature of femininity in the law-making process. Some of the key theories relevant to this study focus on gender difference in terms of equality, difference or being special. Others locate such distinction in the public-private division while post structural feminists deny a universal female experience. The key elements of the theories used in this paper are discussed below.

\section{Equal or different?}

In analyzing the laws governing maternity benefits, the primary question that arises is whether women should be provided special concessions during the period of pregnancy and childbirth. One way to approach this question maybe to emphasize either the equality or the difference between the sexes in the reproduction process.

'Equality feminists' believe that the feminine identity should receive minimal emphasis in the fight for equal rights and equal opportunities in the public domain. 'Equality feminists' such as Phillips (1987) argue that gender differences should be discarded in order to ensure equality of women in the workplace. However, as Guerrina (2001) points out, this approach ignores the inequalities and gendered division of labour in the private sphere and its impact on the public sphere.

'Difference feminists' on the other hand argue that women's needs qua women must be taken into consideration in the formulation of legislation and in decisions governing work policies. Hare-Mustin \& Murecek (1994), for example state that the biological difference between the sexes which is prominently highlighted by pregnancy should not be ignored. They point out that male needs and behaviour should not set the norms of workplace policy to the detriment of the special needs of a pregnant woman. Valarie Bryson (1992) criticizes the equality approach which advocates 'sex blind' or 'gender neutral' legislation on the basis that it undermines feminist struggle for recognition based on differences such as maternity.

Guerrina (2001) queries the validity of the 'difference' view which accepts that men and women are different and have different roles in society so that women possess a 'womanly essence'. She sees this as an implicit acceptance of the association between a woman's biological and social functions of reproduction. Advocating an 
approach which recognizes equality in difference Guerrina (2001) comments that the role of motherhood, which is the primary role of a woman in the private sphere, must be taken into account in ensuring equality for women in the workplace. Evans (1995) has argued that the dichotomy between 'difference' and 'equal' is as artificial as that created between the 'public' and 'private' sphere and that they should be redefined so that they become congruent, recognizing equality in difference. Guerrina (2001) too advocates this view stating that the very meaning attributed to the terms 'equal' and 'different' is based on gender roles and gendered division of labour.

\section{Equal or special?}

In applying these theories of 'equal' or 'different' a key issue is whether pregnancy is unique to women making them 'special' and entitling them to be treated differently. Or as equality feminists argue, does it place them on an equal footing with any employee who becomes temporarily unable to carry out his or her duties and entitle her to treatment equal to such employees? As stated by Vogel (1990) advocates of the 'special' treatment approach such as Krieger and Cooney (1983) believe that real sexual difference constituted by pregnancy makes special treatment necessary to ensure equality. However, Williams (1982) argues that the 'equal' treatment approach is sufficient to entitle pregnant employees, to benefits on the basis of the very real physiological uniqueness of pregnancy which creates burdens on working women which could be compared to other burdensome physiological conditions. However, 'Special' treatment advocates see both the identification of pregnancy as a disability and the acceptance of a male standard of equality as the norm as unacceptable. Finley (1986) argues that where biological differences exist, it must be accepted that women are differently situated. It would appear that those adopting a 'different' and a 'special' stance follow a common line of thinking which contrasts with advocates of 'equality'.

Kay (2013) puts forward a unique proposition when she comments as follows on the two approaches; the equality model recognizes cross sex assimilation as the norm; the difference model 'supports a range of social arrangements from traditional ones, where men and women occupy separate spheres to more androgynous society in which the spheres converge preserving the best characteristics of both sexes'. She then postulates a separate argument viz. that the biological reproductive sexual differences be taken account of and treated as legally significant only when they are used for reproductive purposes. The reproductive differences then are not 
considered as part of sexual identity but merely a functional attribute. She argues that the reproductive differences only become relevant when a party engages in reproductive behaviour. Such behaviour is temporary for males but may last for nine months and end only in childbirth in the case of a woman. If male and female coworkers both engage in reproductive behaviour and the male is not affected as a result while the female is, Kay argues that in order to maintain equality of opportunity between them, the female should not suffer any disadvantage not encountered by the male in the workplace.

\section{The public-private divide}

As Guerrina (2001) argues, maternity legislation focuses predominantly upon women's rights in the official labour market; 'This highlights the extent to which legal structures are founded upon, and in turn support, the division between the public and the private sphere. Thus, the scope of maternity legislation is limited to women's position as pregnant workers in the official labour market. This limitation strengthens the illusory division between the political and the domestic sphere and reaffirms the overwhelming power of the political sphere over the domestic domain'.

The fact that women bear children and men do not is according to Finley (1986) the key impediment to women becoming fully integrated into the public world of the workplace and according to Taub and Schneider (1982) the main factor causing discrimination to women in the workplace and maintenance of the ideology of separate spheres. Finley (1982) comments that this child-bearing role may prevent women obtaining economically lucrative jobs and force them back to the workplace sooner than child development policies advocate. She argues that it is necessary to recognize that the private and public spheres are a continuum each affecting and defining the other. Most employment takes the form of eight-hour five-day week jobs, which do not take into consideration the roles expected of mothers in the private sphere but rather reflect traditional male work norms. As Finley argues if 'rights' are replaced with 'responsibilities' maternity leave can cease to be seen as 'special' treatment but be recognized as benefiting men and children as well.

\section{Post structural feminism}

Post structural feminists deny the notion of a universal womanly experience. Rhode (1992) for example states, that there is no generic woman nor any monolithic 'woman's point of view'. The power of 
gender hierarchies is created and maintained by a traditional definition of woman which disassociates nature and society. The concept of 'woman' is a by-product of a complex set of social and cultural relations. This same is true of maternity and motherhood. As Elam (1990) comments 'woman' is a 'permanently contested site of meaning'. Guerinna (1995) states that though women may experience biological commonalities throughout maternity, 'woman' 'motherhood' and their relationship derives from social networks both in the public and private sphere.

\section{Maternity and the economic theory of opportunity cost}

Apart from feminist theories, Baker and Milligan (2008) discuss a few theoretical models of the decision to breastfeed which would also be of relevance in reviewing maternity legislation. Accordingly Roe et al. (1999) and Chatterji and Frick (2005) explain that the opportunity cost of time spent on breastfeeding will rise significantly with the return to work, and predict a clustering of breastfeeding termination just prior to return. If the mother plans to stop breast feeding on return to work and therefore only contemplates a short period of breastfeeding, the fixed costs in equipment and learning may not exceed the short flow of benefits and, this may result in decreased initiation of breastfeeding. These economic theories are based on the assumption that making the decision to stay away from work plays a more important role in the outcome than the decision to breastfeed.

\section{Methodology}

This study is normative in nature. It seeks to study the various laws governing maternity in Sri Lanka and the benefits provided to a woman during her period of pregnancy and childbirth from a feminist and economic perspective.

Section 21 of Maternity Benefits Ordinance defines 'maternity benefit' as the amount of money payable to a woman under the provisions of that Ordinance; although Part 1A of the Shop and Office Act is headed with the title 'Maternity Benefits', no definition of the term is to be found within the Act. Therefore, the author has adopted the broader meaning for 'benefit', i.e., encompassing all the benefits conferred on a woman during pregnancy and childbirth, for this paper. Accordingly, the study identifies seven key benefits relevant to pregnancy and childbirth, namely, maternity leave, nursing intervals, welfare of mother and baby, job security, pay, crèche facilities and paternity leave. This paper first analyzes the provisions in the Maternity Benefits Ordinance, the Shop and Office 
Employees Act and the Establishment Codes to identify the currently existing laws governing maternity benefits under each of the above headings. These laws are then compared with a view to identifying the consistency of the benefits provided to women working in different sectors. These laws are also compared against international obligations and feminist stances on provision of maternity benefits in order to identify the legislators thought process behind the adoption of specific provisions.

\section{Rationale for granting maternity benefits}

Many reasons maybe identified for maternity leave to be provided to mothers. Guerrina (2008) cites three reasons which guide maternity legislation i.e. protection of women's health and safety; broadening women's rights as workers by for example protecting against dismissal during maternity leave; and protection of the 'special' relationship between mother and child.

The needs of the new-born can be seen as another reason for granting maternity leave. The World Health Organization (WHO) and UNICEF both recommend that babies be exclusively breastfed for the first 6 months of their lives (i.e. 180 days) for optimal development, health and growth. WHO states that all needs of a baby for the first 6 months of its life, up to half its needs between 6-12 months and up to one third of its needs during the second year of life can be obtained from breast milk. This WHO statement in 2015 is based on the findings of a study by Kramer and Karuma (2009) which indicates that exclusive breastfeeding of infants with only breast milk, and no other foods or liquids, for six months has several advantages over exclusive breastfeeding for 3-4 months followed by mixed breastfeeding. These advantages include a lower risk of gastrointestinal infection for the baby, more rapid maternal weight loss after birth, and delayed return of menstrual periods.

Studies by Baker and Milligan (2008) and Bick et al. (1988) however, indicate that there is a strong link between return to work and stopping or never breast feeding a baby. Empirical studies by Kurinij et al. (1989) Gielen et al. (1991) Lindberg (1996) Visness and Kennedy (1997) and Fein and Roe (1998) further support this view.

The International Labour Organization (ILO) has set out international standards for maternity protection by Maternity Protection Convention (Revised) 1952 (No 103). This was superseded by Maternity Protection Convention 2000 (No 183). However, Sri Lanka has not ratified the 2000 Convention and continues to be bound by that of 1952. According to Article 1, the Convention covers 
women employed in industrial undertakings and in non-industrial and agricultural occupations, including women wage earners working at home. Article 3 (2) sets out the minimum period of leave as 12 weeks. Article 3 requires that states provide for additional leave before or after birth if the mother suffers any maternity related illness. Article 4 requires states to provide for maternity benefits sufficient for the full and healthy maintenance of mother and child. Article 5 deals with the requirement for feeding hours while Article 6 prohibits termination of employment during pregnancy. Article 7 provides a ratifying state with the opportunity to exempt itself from applying the convention to certain groups including home workers, domestics and women working in agricultural undertakings other than plantations. However, Sri Lanka has not chosen to exercise this option and all women workers are entitled to its protections.

\section{Maternity legislation in Sri Lanka}

The principle laws governing maternity benefits in the private sector of Sri Lanka are the Shop and Office Employees Act No 19 of 1954 and the Maternity Benefits Ordinance No 32 of 1939. The Establishment Code of Sri Lanka is the law applicable to state sector employees. The provisions dealing with maternity benefits in the Code have been amended by Public Administration Circular No 3 of 2005. The Establishment Code applicable to universities as amended by University Grants Commission Circulars is also considered here in light of its applicability to the University Community.

\section{Applicability of the laws}

The provisions dealing with maternity benefits under the Shop and Office Employees Act No 19 of 1954 are applicable, by virtue of Section 18 (A) to every women working in or in businesses related to shops and offices.

The Maternity Benefits Ordinance No 32 of 1939 covers all "women workers" (other than women employed in or about the business of a shop or an office or a woman whose employment is of a casual nature) who are according to Section 21 of the Ordinance women employed on wages in any trade, whether such wages are calculated by time or by work done or otherwise and whether such contract is expressed or implied, oral or in writing. A trade is further defined by the section to include any industry, business undertaking, 
occupation, profession, or calling.

The Establishment Code contains the provisions applicable to pregnant females employed in the public sector or in Statutory Boards or covered by provisions of the Establishment Code (Chapter XII). Leave entitlements for those falling into these categories, are currently set out under Public Administration Circular No. 3/2005 by which Section 18 of the Code has been amended. The maternity benefits available to a pregnant university officer are set out in University Grants Commission Circular No10/2013. This circular reflects the contents of the Establishment Code prior to Public Administration Circular No. 3/2005.

Therefore, it can be seen that different laws apply to pregnant women depending on their place of employment. While this in itself may not be of significance, the variation of entitlements under the different laws does give rise for concern.

As mentioned above, the Maternity Benefits Ordinance clearly excludes employees whose nature of work is casual from the ambit of the Act. Thus, a casual pregnant employee in a factory for example is not legally entitled to any benefits. There is no such restriction in the Shop and Office Employees Act which covers 'every' female person employed in the business of a shop or office.

Section 18 of the Establishment Code and Section 1 (a) of University Grants Commission Circular 10/2013 specifically state that all permanent, temporary, casual and trainee female officers are entitled maternity benefits. Therefore, there is specific mention of casual employees in these two laws.

Thus, while three groups of casual employees are covered by maternity laws, those governed by the Maternity Benefits Ordinance are not provided with any maternity benefits.

It is a common practice to engage employees for long periods of time in casual positions in Sri Lanka and such employees are a vulnerable group of employees. Thus, all employees other than those covered by the Maternity Benefits Ordinance are protected by legislation. However, the exclusion of this category of employees under the Maternity Benefits Ordinance which covers establishments such as garment factories where employees are 
predominantly women raises the query on why equals are treated differently.

No laws exist to cover employees such as those in domestic service in private households and home workers. This is despite the ratification of the Maternity Protection Convention (Revised) 1952 (No 103). This appears to validate feminist argument on the publicprivate divide. Those not within the official labour market, do not appear to be considered worthy of equal rights as fellow workers in the official labour market. This reluctance to recognize work done within homes is a clear reflection of patriarchal values. The continuing maintenance of an artificial distinction between work done in homes and 'work places' and an undervaluing of household work is particularly incomprehensible in a country where migrant workers earnings as housemaids contribute significantly to Sri Lanka's foreign exchange earnings.

\section{Maternity leave}

Women employees governed by The Shop and Office Employees Act No 19 of 1954 are as a result of an amendment in 1985 entitled to 84 working days leave - 14 days before confinement and 70 after with full pay on the birth of the first and second child [Section 18 (B)(2)]; however for subsequent births this is halved to 42 working days i.e. 14 days before confinement and 28 days thereafter [Section 18 (2) (b)]. Any birth, which occurs when the woman has two children living at the time of confinement, will only entitle the mother to 42 working days. Thus, she is entitled to only 42 days on her second delivery if she has twins on her first delivery and 84 on her third if one of her previous children is no longer living at the time of the subsequent delivery. A still birth - that is a foetus of 28 days gestation - entitles the mother to 42 days leave with pay, 14 days prior to confinement and 28 days thereafter.

According to Section 3 of the Maternity Benefits Ordinance a pregnant employee is entitled to 12 weeks ( 2 weeks before and 10 weeks after confinement) inclusive of holidays (84 calendar days) for the first two births and 6 weeks or 42 calendar days for any subsequent birth if she has two children living. In the event of confinement which does not result in a live birth a woman is entitled to 6 weeks leave. Section 21 defines a confinement as labour 
resulting in the issue of a dead child, live child or viable foetus (foetus of at least 28 weeks or when in doubt, 12 inches in length and at least two pounds in weight).

Female officers to whom the Establishment Code applies are entitled according to Section 18, to 84 working days leave with full pay. Section 18:3:1 entitles a mother to another 84 calendar days with half pay 'to look after the child'. Section 18:4:1 provides for another 84 calendar days no pay leave 'only if it is required for the purpose of looking after the child'. All maternity leave entitlements are available for each birth irrespective of the number of births as no limitations are placed on them as in the case of the Maternity Benefits Ordinance and Shop and Office Employees Act. Further Section 18:2:4 provides for six weeks leave in the event of a still birth or birth where the child dies during the first six weeks after its birth.

The University Grants Commission Circular No 10/2013 entitles a pregnant university officer to 84 working days with full pay (i.e. excluding holidays) for each, live, childbirth. In the case of a still birth or the death of a child before 6 weeks from the date of the childbirth, the mother is entitled to 6 weeks paid leave. Apart from the 84 days leave, a woman can take a maximum of six extra months (inclusive of holidays) no pay leave, either if her child is born abnormal and remains in that state at the end of the leave or, if the mother needs further rest due to complications arising from childbirth.

The discussion of the provisions above highlight some sharp contrasts in the laws governing different groups of workers. For example although only working days are considered in calculating the number of days leave granted to women covered by the Shop and Office Employees Act and Establishment Codes, even holidays are included in the calculation for women covered by the Maternity Benefits Ordinance. Thus the latter are likely to enjoy a lesser total number of days than the former.

A serious shortcoming of the maternity leave in Sri Lanka is the difference in the period of leave granted. It is noteworthy that both the Maternity Benefits Ordinance and the Shop and Office Employees Act provide only half the time period for third or 
subsequent births; it is only under the Establishment Codes that this period remains the same irrespective of the number of births. When the 42 day period is viewed in the light of the economic theories of Roe et al. (1999) and Chatterji and Frick (2005) it could be pointed out that mothers' are more likely to not initiate breastfeeding or terminate it early in the case of the third and subsequent children. This could lead to serious implications when the WHO and UNICEF recommendation of six months exclusive breastfeeding for babies, is considered. It also places serious constraints on such mothers to provide the best care equally for all their children.

The existing provisions are a clear expression of the acceptance of a public-private divide. The woman's role of child-bearing and rearing has been separated from that of employee and the burden has been cast on the woman to decide whether she is willing to have a third child subject to lesser benefits. This is as Finley (1986) has stated a failure to recognize that the private and public spheres are a continuum each affecting and defining the other. If as she argues 'rights' are replaced with 'responsibilities' maternity leave should cease to be seen as 'special' treatment and be recognized as benefiting society as a whole.

The application of different provisions to women placed in an equal position due to pregnancy is itself inexplicable. The private sector laws appear to be drafted from a purely masculine perspective, which does not appear to understand that though pregnancy itself may have commonalities, each pregnancy and birth is unique carrying its own consequences as postulated by postmodern feminists. If a child dies before the mother has a third baby, she is entitled to a larger number of days than if the first two survive; thus a third baby whose elder sibling dies is privileged above the child whose siblings survive. Thus, third born children are treated differently on the basis of the place of work of their mothers. It is noteworthy that on 23rd March 2015, Cabinet approved amendments to the Maternity Benefits Ordinance and the Shop and Office Employees Act removing this anomaly and granting an equal number of days leave. However, the draft bill has not yet been finalized though more than a year has passed since the decision. The author learns that this may be presented to Parliament before the end of the year. The slow progress of these amendments reflects 
a lackadaisical attitude towards the many thousands of women who may be denied a benefit which would have a significant impact on both their own lives and those of their families.

Since the University Grants Commission does not appear to have adopted the 2005 Circular and retains the 2004 provisions by its Circular of 2013, further diversity in leave provisions is created. The university employee in comparison to other state sector employees is only entitled to an additional leave of six months on no pay, and this too only if the child is abnormal or the mother's delivery gave rise to complications. This diversity in availability of leave is also problematic when viewed in light of Sri Lanka's obligations under the Maternity Protection Convention 1952 (No 103) to provide 12 weeks maternity leave. The provisions for extension of leave is a salutary feature, but lack of uniformity in application across all sectors once more raises issues as to how pregnancy and childbirth and the needs arising there from can be viewed so diversely.

\section{Nursing intervals}

The Shop and Office Employees Act does not provide mothers with nursing intervals after returning to work.

However, according to Section 12B of the Maternity Benefits Ordinance nursing mothers are entitled to two, one hour nursing intervals per day until the child is one year old although the time period maybe reduced to half an hour per interval if the employer provides crèche facilities as the mother would have easy access to the child.

The Establishment Code entitles a mother to leave one hour early once she returns to work after maternity leave till the child is six months old in order to breast feed the child (Section 18:7).

Commission Circular 10/2013 by Section 1 (B) grants a mother two half hour nursing intervals after resumption of duties either till the child reaches one year or for six months whichever occurs earlier.

Thus, a wide disparity is seen with regard to nursing intervals, with women in shops and offices not receiving any concessions for nursing their children. Those in trades and factories receive two hours a day while state employees receive only one hour a day. 
Among state sector employees too, a difference can be seen; University staff are entitled to a nursing period till the child is one year old but other state employees only get this benefit until the child is six months.

The WHO recommendations for breastfeeding and the advantages to both mother and child which result from it, clearly dictate that sufficient provisions should exist to encourage this practice. The studies by Milligan (2008), Bick et al. (1988) 1989) Gielen et al. (1991) Lindberg (1996) Visness and Kennedy (1997) and Fein and Roe (1998) all indicate that there is a strong link between return to work and stopping or never breastfeeding a baby. Roe et al. (1999) and Chatterji and Frick's (2005) explanation that opportunity cost of time spent on breastfeeding will rise significantly with the return to work, and lead to a cluster of breastfeeding termination just prior to return to work mandate that sufficient opportunity to breastfeed be provided in order to stop this trend. Therefore, in addition to sufficient leave, it is also important to provide incentives to continue breastfeeding after returning to work, and provision of nursing intervals is one such mechanism that can and should be adopted. The nursing intervals may be seen as especially important for women who have more than two children since their period of leave is also of shorter duration.

Thus while the concessions given are salutary, its limited application needs to be addressed. Also the practical value of the time duration given must be considered in light of modern times when many women commute long distances to get to their workplaces and road networks are highly congested. Finley's arguments on the publicprivate divide hold true with regard to nursing intervals as well. While breastfeeding has by nature been cast on the woman, legislators cannot ignore the special position in which it places her, rendering her different to man.

\section{Health and safety of mother and child}

Section 18 (D) (1) of the Shop and Office Employees Act and Section 10 (B) (1) of the Maternity Benefits Ordinance prohibit the employment of a pregnant woman in any work which may be injurious to the woman or her child during the last three months of her pregnancy. Section 18 (D) (2) of the Shop and Office Act and 
Section 10 (B) (2) of the Maternity Benefits Ordinance extend this protection to three months after confinement as well so that such women have to be provided safe employment for a total of 6 months - 3 months pre and 3 months post confinement-respectively.

While similar provisions are not seen in the laws governing the state sector, Section 18:6 of the Establishment Code permits a women to arrive for work and leave office half an hour earlier than the normal time from end of the fifth month of pregnancy. A similar provision is seen in Section 1(c) of the circular governing university officers. These are provisions not available to employees in the private sector.

The Maternity Benefits Ordinance contains a prohibition of knowingly employing a woman during the first four weeks after her confinement (Section 2). A similar provision can be found in Section 1 a) (i) of the University Grants Commission Circular and Section 18:2:1 of the Public Administration Circular as well.

Additionally, as discussed above, University Officers may obtain an additional six months no pay leave under section 1 (d) (i) and 1 (d) (ii); in situations where the child is in an abnormal condition requiring the mothers personal care and where the mother is suffering due to complications arising from childbirth. State employees can also obtain 84 days on half pay and another 84 days no pay leave if required for the purpose of looking after the child according to Sections18(3) and 18(4) respectively. Such additional leave is not provided for under the laws applicable to non-state employees.

As discussed under leave provisions, mothers suffering still births are also entitled to leave. Mention of miscarriage is however only found in Section 18:2:4 of Public Administration Circular according to which there is no provision for miscarriage other than the ability for the woman to avail herself of any vacation leave entitlement on submission of a medical certificate. A still birth or birth of a child who dies within six weeks of birth entitles the woman to six weeks paid leave under section 18:2:4 of the above Circular. Section 3(b) (ii) of the Maternity Benefits Ordinance also provides for two weeks preconfinement and four weeks post confinement where the delivery does not result in a live child. Similarly Section 18(B)(2) provides for 14 days pre-confinement and 28 days post confinement if a live child does not result from the delivery. 
Thus, the law contains many provisions protecting the health of both the mother and child. What is once more problematic is the manner in which these laws apply. Clearly it would be of great value if a common code governing all pregnant women was introduced ensuring uniform application.

\section{Job security}

Section 10 of the Maternity Benefits Ordinance prohibits the issuance of notice of termination to a woman while she is on maternity related leave. A similar provision exists in Section 18 (F) of the Shop and Office Employees Act

Section 10 (A) (1) of the Maternity Benefits Ordinance protects a woman from dismissal due to pregnancy, confinement or any illness arising there from. Section 10 (A) (2) places the burden of proving that a termination made during pregnancy, confinement or an illness resulting thereof was not a result of these circumstances but due to some other reason, on the employer. Similar provisions exist in Sections 18 (E) (1) and (2) respectively of the Shop and Office Employees Act.

No provisions specifically dealing with termination of services during maternity leave are contained in the University Grants Commission Circular No 10/2013 or Public Administration Circular 4/2005. However, Circular 10/2013 contains a provision applicable when a woman takes additional no pay leave; this provision [Section 1(d) (iv)] provides that a woman should not suffer any constraints in terms of increment of salary, pension or promotion as a result of availing herself of such leave. Section 18:9 of Circular 4/2005 contains a similar provision regarding the use of half pay and no-pay leave.

The guarantee of job security is a laudable feature of the legislation. It may be seen as one instance where the public-private divide has actually been broken down to acknowledge the dual role of women in modern society. It also echoes the view of Kay (2013) that a woman alone should not be discriminated against, due to engaging in reproductive behaviour. Once more however, a lack of uniformity across the laws which needs addressing is noted. 


\section{Pay during leave period}

As seen in the section dealing with leave, all maternity leave given immediately after the birth of a child is with full pay. Additionally, University and state officers are also provided with half pay and no pay leave, above and beyond the original amount of paid leave.

Section 5 of the Maternity Benefits Ordinance as amended by section 43 of 1985 entitles a woman to full payment during her period of maternity leave, while section 5 (3) enables an employer to provide alternative maternity benefits to women employed on his/her estate in lieu of those set out in the Ordinance. Section $18(C)$ of the Shop and Office Act also requires the employer to provide full pay for the employee during the period of maternity leave.

Section 18:2:1 of Public Administration Circular 4/2005 entitles a woman to 84 working days on full pay for each live birth and 6 weeks for a still birth or where the child does not survive the first six weeks of birth. In addition, state sector employees can also claim half pay for another 84 days if they need to take care of their children beyond the original leave period during which they were fully paid.

University officers are not entitled to half pay leave. Their entitlement of paid leave is limited to 84 working days for each live birth and six weeks for a still birth or birth of a child who does not survive six weeks according to Circular No 10/2013 (Section 1 (a) (i) and (iv).

The provision of paid leave for the initial period of maternity which is provided across all legislation, once more recognizes the dual role of a woman and the continuum between the public and private spheres. Of course, the limitation of the period of paid leave in the event of the third child under the Maternity Benefits Ordinance and the Shop and Office Employees Act as discussed above limits its efficacy. The limited application of half pay and no pay to specific groups of employees, and the difference in the conditions to which such leave is subject however leads to discrimination among new mothers. It is also questionable as to how many women would utilize this additional leave due to limitation of payment. In an era where 
the cost of living requires two incomes for a family to survive, availing oneself of no-pay leave may not be a luxury a young mother could afford. In such a situation, the provision of leave may be of little practical use.

\section{Crèche facilities}

Section 12 (A) (1) of the Maternity Benefits Ordinance requires an employer of more than a prescribed number of women workers in any trade to establish and maintain, in accordance with regulations made governing it, a crèche for children under five years of age. Any worker should be allowed to leave her children within that age in the crèche while she is working.

Such a requirement for crèche facilities is not seen in any of the other legislation. A clear application of the public-private divide seems to operate in these cases. No responsibility for the welfare of the child has been cast on the employer. The legislation does not take cognizance of the difficulties of a woman in carrying out her dual roles in the public and private spheres. In the modern nuclear family, one of the greatest problems a woman returning to work after childbirth faces is finding a day care or other safe and affordable facility in which to keep her child while she is at work. The availability of crèches in the workplaces could prevent many women from being forced to make the difficult decision to giving up work once they start a family.

Only the Maternity Benefits Ordinance provides discretion for the employers to provide alternative maternity benefits to those provided by law and also includes provision for regulations to compel employers to provide crèche facilities for children of their employees. This is a salutary provision since the highest number of female employees is seen in the estate sector.

\section{Paternity leave}

Section 18 of the Establishment Code as amended by Public Administration Circular 3/2006 has introduced 3 days paternity leave to any permanent, temporary, casual or trainee public officer on the birth of a child to such officer's wife, which has to be used within three months of the birth. The marriage certificate of the 
officer and birth certificate of the child are required when applying for this leave. The purpose of providing three days leave has not been specified, and in terms of caring for a new born, it seems meaningless. However, no provisions of paternity leave are found in any of the other legislation and on this basis alone it may be considered a progressive step. Unfortunately however, the role a father is envisaged to play in the child rearing-process appears to be in line with patriarchal thinking; namely that it is limited to the act of procreation and possibly celebrating the birth of the child.

An in depth discussion of the father's role is beyond the scope of the present discussion. However, the lack of any recognition of a role emphasizes the argument that law makers maintain a strict publicprivate divide in which the role of child-rearing appears to remain vested solely with the female. The distinction between child-bearing and parenting does not appear to have penetrated into the understanding of legislators who still seem to perceive it as an essentially female role.

\section{Conclusions}

The above analysis of the maternity legislation in Sri Lanka indicates the wide disparity in content applicable to women governed by the different laws.

Several shortcomings maybe viewed across the legislation; failure to provide benefits to casual workers under the Maternity Benefits Ordinance; lack of legislation covering home workers; lesser number of days leave given to mothers governed by the Maternity Benefits Ordinance and Shop and Office Employees Act having more than two children; non availability of nursing intervals to mothers under the Shop and Office Employees Act; lack of provisions for half pay and no pay leave to women in the private sector; the absence of provision for paternity leave except three days for government employees; and non-inclusion of a requirement to provide crèche facilities except under the Maternity Benefits Ordinance.

What is the reason for this lack of uniformity in laws applicable to women working in the same country? Have different considerations played a role in their formulation? What justifies the fact that employees in the private sector offices, shops and trades enjoy lesser benefits than the state sector employees? 
Government employees clearly enjoy the greatest advantage in respect to most benefits. They are entitled to the same number of days leave irrespective of the number of children as well as nursing intervals; they are also entitled to half pay and no pay leave beyond the initial period, enabling a woman to make the choice to stay home in order to breastfeed and care for her baby for a longer period of time. While the limitation in pay may affect a woman's decision whether to avail herself of this leave, the very availability is an advantage women employed in other sectors do not enjoy. In contrast, a woman in a university is only entitled to no pay leave, after the initial leave and this too only on the basis of medical need, so that it is a very limited choice. The non- adoption of the most recent Public Administration Circular by the University Grants Commission too which retains provisions less favourable to women, reflects a lack of understanding of the need to break down the barriers between the public and private sphere and a failure to appreciate the importance of the social role women fulfill.

State sector employees are also the only category of employees entitled to paternity leave. Although the quantum of leave may be questionable it at least makes some token acknowledgement that a father too should play a role in the initial care of a new-born.

In contrast, women governed by the Shop and Office Employees Act and Maternity Benefits Ordinance do not have any additional leave entitlement beyond the initial leave which in itself is halved after the second birth. This is in spite of the fact that the state has by ratifying the Maternity Protection Convention, undertaken to provide sufficient leave and benefits. Since casual employees are not covered under the Maternity Benefits Ordinance, this group is particularly vulnerable; although it may be argued that practical difficulties can arise in applying these benefits to persons whose employment is 'casual' it could prevent a person being terminated due to pregnancy alone and becomes important in the light of practical reality where persons are employed in 'casual' positions for long periods of time. Women in shops and offices alone are not entitled to nursing hours, leading to a situation where a mother having a third child has only 42 days leave with no nursing intervals or provision to take additional no pay or half pay leave even if her child requires special attention.

The reduction in leave provided for delivery of babies beyond the second child may be seen as a policy decision to discourage women from having larger families. It could also be intended to place a limitation of the burden on employers to provide maternity benefits and a reduction of the possibility of losing an employee's services for 
long periods if they decide to have large families. However, when the state sector laws provide for an equal number of days irrespective of the number of children and also provides for further leave with half pay and no pay, it raises questions as to the basis on which this stance has been adopted solely for the private sector.

It could also be counter argued that mandatory provision of greater periods of maternity leave and nursing intervals would make women of child-bearing years less attractive to employers who may view them as liabilities. This is especially true of the private sector which is primarily driven by profit. Also discrimination in selecting employees on the basis of sex cannot be challenged in the private sector where the largest numbers are employed, as the constitutional protections are only available against executive and administrative actions. Thus, including broader maternity benefits in laws governing the private sector may indirectly have a negative impact on women during the recruitment process. Only a change in perception of employers that there is no division between public and private spheres will effectively ensure that women benefit fully from maternity legislation. The likelihood of this happening would only increase when more women occupy top positions in organizations.

In Sri Lanka, maternity leave is not seen as 'disability' leave but clearly set out as maternity leave. Therefore, it may be argued that the basis of maternity benefits is not 'equality' but 'difference' or being 'special'. Nevertheless, it would appear that Guerrina's (2008) argument that maternity legislation is determined by the official labour market is affirmed by the laws governing the private sector. For example, the halving of maternity leave after the second child is a clear failure to recognize the 'special' nature of pregnancy. It contradicts all laws of nature applicable to the mother and child, and can only be understood in the light of the requirements of the official labour market. The profit driven private sector appears to maintain a sharp public-private divide and does not appear to make allowance for the broader social role women play through reproduction. The standard male norm is applied to women so that upon her resumption of duties, no provisions exist to enable her to balance her dual roles as employee plus mother and care giver. The pre-existing norm that men played no active role as care giver in the private sphere is perpetuated through lack of any mechanism to ensure his involvement in raising the family; at the same time this same 'equal' standard is applied to women ignoring the reality of her dual role. This reaffirms Finley's (1982) argument that the standard is set based on traditional male work norms. 
The artificial division between the public and private spheres is seen across all laws dealing with maternity benefits. The role of child rearing is still primarily cast on the woman in Sri Lanka, and legislation has done little to change this by providing meaningful parental or paternity leave. Nor has it evolved to remove barriers women face and help them fulfil their dual roles by providing crèches, or acceptable maternity leave and nursing hours.

It is therefore, the author's contention that though the Sri Lankan legal framework, by providing protected and paid maternity leave has given some measure of protection to women, the lack of uniformity among the laws has created difference among women who are equally situated. Each law dealing with maternity benefits reflects a different legislative intention so that the maternity laws taken as a whole, lack uniformity and discriminate employees of different sectors on no justifiable ground. Therefore, a uniform law applicable to all employees needs to be enacted to address this situation and ensure that all women are given equal benefits to successfully establish a continuum between their home and work lives.

\section{References}

Abeykoon, A. T. P. L., Rannan-Eliya R. P., Wickremasinghe, R., Thowfeek, R., Anuranga, C. and Siriwardena Abeykoon, I. (2014) Study on the Establishment of Maternity Protection Insurance in Sri Lanka. Institute for Health Policy

Baker M and Millgan K (2008). Maternal employment, breastfeeding, and health: Evidence from maternity leave mandates. Journal of Health Economics 27, 871-887 journal homepage: www.elsevier.com/locate/econbase accessed 27th March 2016 https://doi.org/10.1016/j.jhealeco.2008.02.006

Bick, D., Macarthur, C., and Lancashire, R, (1999). What influences the uptake \& early cessation of breast feeding? Midwifery 14 (4):242https://www.researchgate.net/publication/13215220_ What_influences_the_uptake_early_cessation_of_breastfeeding accessed 27th March 2016

Bryson, V., (1992). Feminist Political Theory; an Introduction. London, Macmillan.

https://doi.org/10.1007/978-1-349-22284-1

Chatterji, P., Frick, K. D., 2005. Does returning to work after childbirth affect breastfeeding practices? Review of Economics 
of the Household 3 (3), 315-335. https://doi.org/10.1007/s11150-005-3460-4

Elam, D. (1994). Feminism and Deconstruction; Ms and Abyme. London and New York, Routledge.

Establishment Code of the Government of the Republic of Sri Lanka, Ministry of Public Administration and Local Government

Evans, J. (1995). Feminist Theory Today: an introduction to second wave feminism. London, Sage.

Fein, S. B., Roe, B., 1998. The effect of work status on initiation and duration of breast-feeding. American Journal of Public Health 88 (7), 1042-1046.

https://doi.org/ 10.2105/AJPH.88.7.1042.

Finley, L. (1986) Transcending Equality Theory: A Way out of the Maternity and the Workplace Debate. Columbia Law Review, Vol. 86, No. 6 pp. $1118-1182$

https://doi.org/10.2307/1122655

Gielen, A. C., Faden, R. R., O'Campo, P., Brown, C. H., Paige, D. M., 1991. Maternal employment during the early postpartum period: effects on initiation and continuation of breastfeeding. Pediatrics 87 (3), 298-305

Guerrina, R. (2001). Equality Difference and Motherhood: The Case for a Feminist Analysis of Equal Rights and Maternity Legislation, Journal of Gender Studies, 10:1, 32-42 https://doi.org/10.1080/095892301300050555

Hare-Mustin, R. T. \& Murecek, J (1994). Gender and the Meaning of Difference Post Modernism and Psychology in: A. C. Herrman $\&$ A.J. Steward (Eds) Theorizing Feminism: Parallel Trends in the Humanities and Social Sciences. San Francisco and Oxford, Westview

Kay, H. H. (1985). Equality and Difference; the case of pregnancy. 1 Berkley.Women's..LJ.1.Availableat..http//:scholarship.law.be rkley.edu/bglj/vol1/issue 1/1 (Sept 2013)

Kramer, M. S. and Kakuma, R. (2009). Optimal duration of exclusive breastfeeding (Review). The Cochrane Library, Issue 4

Krieger, L.J. and Cooney, P. (1982). The Miller-Wohl Controversy: Equal Treatment, Positive Action and the Meaning of Women's 
Equality. Golden Gate University Law Review 13, 513-72

Kurinij, N., Shiono, P. H., Ezrine, S. F., Rhoads, G. G., (1989). Does maternal employment affect breast-feeding? American Journal of Public Health 79, 1247-125

https://doi.org/10.2105/AJPH.79.9.1247

Lindberg, L. D., (1996). Women's decisions about breastfeeding and maternal employment. Journal of Marriage and the Family 58 (1), 239-251.

Maternity Benefits Ordinance No 32 of 1939.

Phillips, A. (1987). Introduction in: A. Phillips (Ed) Feminism and Equality. Oxford, Brazil, Blackwell https:/ /doi.org/10.1017/cbo9780511621918.002 https://doi.org/10.1016/0014-2921(87)90011-0

Public Administration Circular No. 3/2005.

Roe, B., Whittington, L. A., Fein, S. B., Teis1, M. F., 1999. Is there competition between breast-feeding and maternal employment? Demography 36, 157-171. https:/ / doi.org/10.2307/2648105.

Rhode, D. L. (1992). The Politics of Paradigms; gender difference and gender disadvantage in Beyond Equality and Difference; citizenship feminist politics and feminine subjectivity. London and New York Routledge.

Shop and Office Employees Act No 19 of 1954.

Sri Lanka Labour Force Statistics, Quarterly Bulletin; Sri Lanka Labour Force Survey (2014). Issue No 64, Department of Census and Statistics, Ministry of Finance and Planning Sri Lanka.

Sri Lanka Labour Force Statistics, Quarterly Bulletin; Sri Lanka Labour Force Survey (2015). Issue No 68, Department of Census and Statistics, Ministry of Policy Planning Economic Affairs, Child Youth and Cultural Affairs.

Sri Lanka Labour Force Survey Annual Report (2014). Department of Census and Statistics Ministry of Policy Planning and Economic Affairs, Child Youth and Cultural Affairs, Battaramulla.http://www.statistics.gov.1k/samplesurvey/LFS _Annual\%20Report_2014.pdf accessed 27th March 2016 
Taub, N. and Schneider, E. (1982). Perspectives of Women's Subordination and the Role of Law, D. Kairys (Ed), The Politics of Law 117.

University Grants Commission Circular No10/2013.

Visness, C. M., Kennedy, K. I., (1997). Maternal employment and breast-feeding: Findings from the 1988 national maternal and infant health study. American Journal of Public Health 87 (6), 945-95 https://doi.org/10.2105/AJPH.87.6.945.

Vogel, L. (1990) Debating Difference: Feminism, Pregnancy, and the Workplace. Feminist Studies, Vol. 16, No. 1. 9-32 https://doi.org/10.2307/3177954.

Williams, W. (1982). The Equality Crisis: Some Reflections on Culture, Courts and Feminism; Women's Rights Law Reporter, 7 175-200.

World Health Organization Statement (2011). Exclusive breast feeding for six months best for babies everywhere http://www.who.int/mediacentre/news/statements/2011/br eastfeeding_20110115/en/accessed 30th March 2016.

Received: 31-03-2016 Revised: 28-08-2016

Accepted: 04-09-2016 